\title{
IN VITRO ANTIMICROBIAL, ANTIBIOFILM AND CYTOTOXIC ACTIVITIES OF THE EXTRACTS OF ARUM ITALICUM MILLER LEAVES
}

\author{
MAYRAM HACIOGLU ${ }^{1}$, BUSRA KULAKSIZ ${ }^{2}$, KERIM ALPINAR ${ }^{3}$, EBRU HACIOSMANOGLU ${ }^{4}$, \\ A. SEHER BIRTEKSOZ TAN ${ }^{1 *}$
}

${ }^{1}$ Department of Pharmaceutical Microbiology, Faculty of Pharmacy, Istanbul University, Beyazit, Istanbul, 34116, Turkey

${ }^{2}$ Department of Pharmacognosy, Faculty of Pharmacy, Biruni University, Zeytinburnu, Istanbul, 34010, Turkey

${ }^{3}$ Department of Pharmaceutical Botany, Faculty of Pharmacy, Biruni University, Zeytinburnu, Istanbul, 34010, Turkey

${ }^{4}$ Department of Biophysics, Faculty of Medicine, Bezmialem Vakıf University, Fatih, Ístanbul, 34093, Turkey

*corresponding author: seherbirteksoz@hotmail.com

Manuscript received: November 2020

\begin{abstract}
In this study, the antimicrobial, antibiofilm and cytotoxic activities of four different extracts which were prepared from the leaves of Arum italicum Miller, were investigated against various pathogenic microorganisms. The minimum inhibitory concentration (MIC) values of the extracts were determined by a microdilution method according to CLSI criteria. Inhibition of biofilm adhesion and biofilm formation tests were performed for extracts showing antimicrobial activity. In addition, the cytotoxic activities and anti-proliferative effects of the extracts were examined by the MTT viability test on the human umbilical vein endothelial cell line (HUVECs) and human breast cancer line (MDA-MB-231). The obtained results suggest that $A$. italicum extracts showed antimicrobial activity and were effective for inhibiting the pre-formed biofilms. In addition, the extracts significantly reduced the cell viability in the breast cancer cell line. According to our results, A. italicum extracts can be used as antimicrobial, antibiofilm and anticancer agents.
\end{abstract}

\section{Rezumat}

Studiul prezintă activitatea antimicrobiană, antibiofilm și citotoxică a patru extracte preparate din frunze de Arum italicum Miller, studiate asupra mai multor specii microbiene. Concentrația minimă inhibitorie a fost determinată prin metoda microdiluției. Inhibiția adeziunii biofilmului și testele de formare a biofilmului au fost determinate pentru extractele care au prezentat activitate antimicrobiană. Activitatea citotoxică și efectele anti-proliferative ale extractelor au fost evaluate folosind testul MTT pe două tipuri de linii celulare: HUVEC și MDA-MB-231. Rezultatele arată că extractele prezintă activitate antimicrobiană şi de inhibare a biofilmului, alături de reducerea viabilității celulelor MDA-MB-231. Astfel, extractele de Arum italicum Miller pot fi considerate potențiale substanțe anticancerigene.

Keywords: antimicrobial activities, antibiofilm activities, cytotoxic activities, Arum italicum

\section{Introduction}

Plants have been used worldwide for centuries, in folk medicine; in herbal tea preparations, spices and for therapeutic purposes [23]. In particular, medicinal plants with antimicrobial effect have gained importance as concerns have been expressed about the rising prevalence of pathogenic microorganisms, which are resistant to modern antibiotics [19]. In this context, studies have been conducted which reported that plant extracts and natural substances obtained from various parts of the plants have antimicrobial properties against bacteria and fungi $[2,24,34]$. The Araceae family is represented in Turkey by 32 taxa, consisting of 5 genera (Arisarum Mill., Arum L., Biarum Schott, Dracunculus Schott, Eminium (Blume) Schott), 22 species, 5 subspecies and 12 varieties [9, 20, 27, 28]. Arum is the largest genus among the other aroids of Turkey. Representatives of the genus are distributed in
Central Asia, Europe, Macronesia, the Mediterranean and the Middle East regions. Arum taxa have been familiar to Eastern Mediterranean people for centuries. Arums have many vernacular names; "Yılan Bıçağı", Yılan Burçağı", "Yılan Kaması" and "Yılan Yastı̆̆ıı" ("Serpent knife"; "Serpent dagger"; "Serpent vetch"; "Serpent pillow" respectively, in translation from Turkish) are most common among them [5, 6]. Arum italicum belongs to the Arum class of the Araceaa family which is an angiosperm, a monocotyledonous perennial plant. The species in the Arum genus most discussed in the literature are Arum palaestinum and Arum maculatum. A review of the literature determined that, there are a limited number of studies of antimicrobial effects of $A$. italicum extracts [3,9].

Tubers, leaves and fruits of $A$. italicum are mainly used as a traditional medicine and food industry in Turkey. While the leaves are boiled in water and consumed as wraps and salads, is common for the 
whole plant to be cooked with rice and bulgur and used to reduce the labour pain.

Biofilms are communities of microbial cells adherent to biotic or abiotic surfaces within an extracellular matrix [11]. According to the National Institutes of Health, biofilms are estimated to account for over $80 \%$ of all nosocomial infections and are particularly common with device implants, such as contact lenses, ventricular assist devices, vascular and urinary catheters and endotracheal tubes $[7,12]$. Because the use of conventional antimicrobial compounds in many cases cannot eradicate biofilms, there is an urgent need to develop alternative compounds and approaches to combat biofilm-based infections [4, 21]. For this purpose, in this study, the effects of four different extracts prepared from leaves of A. italicum, on the inhibition of biofilm adhesion and biofilm formation were investigated against various pathogenic microorganisms. In addition, $A$. italicum extracts were tested on the human umbilical vein endothelial cell line (HUVECs) and the human breast cancer cell line (MDA-MB-231) by MTT assay, to assess their anticarcinogenic effects.

\section{Materials and Methods}

Preparation of plant materials and extracts

The plant materials were collected from Istanbul and deposited as herbarium samples at the Biruni University, Turkey, Faculty of Pharmacy. The leaves of the plant were air-dried in shade at room temperature, then, they were ground into fine powder using an electric blender. The powdered plant materials $(30 \mathrm{~g})$, were extracted with $300 \mathrm{~mL}$ of four solvents (acetone, ethanol, methanol, distilled water) (plant material to solvent ratio was $1: 10, \mathrm{~m} / \mathrm{v}$ ) for 72 hours at room temperature. Extracts were filtered through Whatman No.1 filter paper. All filtrates were concentrated and evaporated at $40^{\circ} \mathrm{C}$ until dry and were maintained at $+4^{\circ} \mathrm{C}$ until further experiments [25, 31].

Antimicrobial activity

The in vitro antimicrobial activities of the extracts were determined using the microbroth dilution technique described by the Clinical and Laboratory Standards Institute (CLSI) [13, 14]. The minimum inhibitory concentrations (MICs) of the extracts were investigated against Staphylococcus aureus ATCC 29213, Staphylococcus epidermidis ATCC 12228, Escherichia coli ATCC 25922, Klebsiella pneumoniae ATCC 4352, Pseudomonas aeruginosa ATCC 27853, Proteus mirabilis ATCC 14153, Candida albicans ATCC 10231, Candida parapsilosis ATCC 22019 and Candida tropicalis ATCC 750. Serial twofold dilutions ranging from 5000 to $4.8 \mu \mathrm{g} / \mathrm{mL}$ were prepared in MuellerHinton broth (MHB) (Difco, Detroit, MI, USA) for bacteria and RPMI-1640 medium (Sigma, St. Louis, MO, USA) buffered to $\mathrm{pH} 7.0$ with MOPS for yeasts, dimethylsulfoxide (DMSO, Sigma, St. Louis, MO, USA) was used as a solvent for the extracts. Each well was inoculated with $50 \mu \mathrm{L}$ of a $4-6 \mathrm{~h}$ broth culture to give a final concentration of $5 \times 10^{5} \mathrm{CFU} /$ $\mathrm{mL}$ for bacteria and $0.5 \times 10^{3}$ to $2.5 \times 10^{3} \mathrm{CFU} / \mathrm{mL}$ for yeast in the test trays. The trays were covered and placed in plastic bags to prevent evaporation. The trays containing $\mathrm{MHB}$ were incubated at $37^{\circ} \mathrm{C}$ for $24 \mathrm{~h}$, while those containing the RPMI-1640 medium were incubated at $30^{\circ} \mathrm{C}$ for $48 \mathrm{~h}$. The MIC of each extract was defined as the lowest concentration of compound required for complete inhibition of visible growth. Ciprofloxacin and fluconazole were used as reference antimicrobials for bacteria and yeast, respectively. Also as a control, the antimicrobial effects of the DMSO were investigated using microorganisms. The results were evaluated according to the control values. The MIC values of ciprofloxacin and fluconazole were within the accuracy range in CLSI throughout the study.

Biofilm attachment assay

After MIC assay, inhibition of biofilm attachment and biofilm formation assays were performed on those compounds which showed antimicrobial effects. Biofilm attachment assay was performed using the previously described method, with some modifications $[10,17]$. The overnight cultures of isolates were prepared to a cellular density equivalent to $1 \times 10^{7}$ cells $/ \mathrm{mL}$ for bacteria and $1 \times 10^{6}$ cells $/ \mathrm{mL}$ for yeasts. Microorganisms were added to each well of 96-well tissue culture microtiter plates with $1 / 10 \mathrm{x}$ MIC $(\mathrm{MIC}=625-312.5 \mu \mathrm{g} / \mathrm{mL})$ of plant extracts. The positive control without plant extracts and negative control without cells were also added. The plates were incubated for 1,2 and $4 \mathrm{~h}$ at $37^{\circ} \mathrm{C}$ for bacteria and 2, 4 and $6 \mathrm{~h}$ at $37^{\circ} \mathrm{C}$ for yeast. After incubation, the wells were washed twice with PBS (phosphate buffered saline) solution and were measured spectrophotometrically at $450 \mathrm{~nm}$, on a microplate reader (BioRad Novapath).

\section{Inhibition of biofilm formation}

Bacteria $\left(1 \times 10^{5}\right.$ cells $\left./ \mathrm{mL}\right)$ and yeast $\left(1 \times 10^{6}\right.$ cells/ $\mathrm{mL}$ ) were added to each well of a 96-well tissue culture microtiter plate with $1 \times$ MIC, $1 / 10 \times$ MIC and $1 / 100 \times$ MIC $(\mathrm{MIC}=625-312.5 \mu \mathrm{g} / \mathrm{mL})$ of plant extracts. The positive control without plant extracts and negative control without cells were also added. The plates were incubated for $24 \mathrm{~h}$ at $37^{\circ} \mathrm{C}$. After incubation, the wells were washed twice with PBS and were measured spectrophotometrically at $450 \mathrm{~nm}$, on a microplate reader (BioRad Novapath) [8, 17].

Cell culture and plant extracts treatment

For revealing of anticarcinogenic effects of Arum extracts on breast cancer, HUVECs and MDA-MB231 cell lines were obtained from the American Type Culture Collection (Virginia, USA). The cells were cultured at $37^{\circ} \mathrm{C}$ in a humidified incubator containing 
FARMACIA, 2021, Vol. 69, 5

$5 \% \mathrm{CO}_{2}$ in Dulbecco's modified Eagle's mediumF12 (DMEM-F12; Gibco; Thermo Fisher Scientific, Inc., Waltham, MA, USA) supplemented with $10 \%$ foetal bovine serum (FBS; Gibco; Thermo Fisher Scientific, Inc.) and 1\% Penicillin Streptomycin (Sigma, USA). The cells were maintained in the logarithmic phase of growth and sub-cultured every $3-4$ days. Before treatment, $3 \times 10^{3}$ cells in each group were plated in a 96-well plate. After $24 \mathrm{~h}$ of cell plating, the cells were incubated with ethanol and acetone extract from A. italicum in increasing concentrations $(5,12.5,25$ and $50 \mu \mathrm{g} / \mathrm{mL})$ for $48 \mathrm{~h} \mathrm{[29].}$

Cell Viability Assay

After treating the cells with extracts of $A$. italicum, cell viability was determined using colorimetric 3(4,5-dimethylthiazol-2-yl)-2,5-diphenyltetrazolium bromide (MTT) reduction assay that measures the activity of mitochondrial dehydrogenase. An MTT solution $(5 \mathrm{mg} / \mathrm{mL})$ was prepared by dissolving MTT powder in PBS, and the solution was filter-sterilized (0.22 $\mathrm{mm}$ pore size filter). Thereafter, MTT was transferred to each well containing cells and incubated in the dark for $3 \mathrm{~h}$ at $37^{\circ} \mathrm{C}$. After incubation, the supernatant was decanted and DMSO was added to the cells. The optical density of the supernatant was measured at $570 \mathrm{~nm}$ with a microplate reader (Epoch Microplate Spectrophotometer, Biotek) [26]. Every concentration was repeated in three wells and then the half-maximal inhibitory concentration $\left(\mathrm{IC}_{50}\right)$ values were calculated with a GraphPad Prism. Data were presented as mean \pm SEM of at least triplicate determinations.

\section{Results and Discussion}

Nowadays, although there are studies in the literature about the biological effects of many species in the Arum genus, there are limited studies on A. italicum activities in vitro $[1,3,16,18,30]$. The current investigations clearly indicate that antibacterial and anticandidal activity vary with the species of plant. In this study, it was determined that ethanol and acetone extracts prepared using the leaves of $A$. italicum plant were effective against $S$. aureus, $S$. epidermidis, $P$. aeruginosa, $C$. albicans and $C$. tropicalis, while the distilled water and methanol extracts had no effect against microorganisms. It was seen that both polar and apolar substances pass into ethanol used as a solvent in our study, whereas only polar substances passed into methanol. Therefore, the activity difference between ethanol and methanol extracts may be occurred due to the difference in the content of the extracts. The ethanol extracts were found to be active against $S$. aureus, $S$. epidermidis, $P$. aeruginosa, $C$. albicans and $C$. tropicalis, with MIC values which were identified as $625 \mu \mathrm{g} / \mathrm{mL}$ for bacteria and C. albicans, and $312.5 \mu \mathrm{g} / \mathrm{mL}$ for $C$. tropicalis. Furthermore, acetone extract was effective against $S$. epidermidis and $C$. tropicalis with MIC values which were determined as $625 \mu \mathrm{g} / \mathrm{mL}$ and $312.5 \mu \mathrm{g} /$ $\mathrm{mL}$, respectively (Table I). These results showed that A. italicum leaf extracts may have the potential to be used as an antibacterial agent in the research of new drugs.

Table I

MIC values of extracts against microorganisms

\begin{tabular}{|l|c|c|c|c|c|c|c|c|c|}
\hline \multicolumn{9}{|c|}{ MIC values $((\mu \mathrm{g} / \mathrm{mL})$} \\
\hline Extracts & S.a & S.e & E.c & K.p & P.a & P.m & C.a & C.t & C.p \\
\hline 1/10 Ethanol & 625 & 625 & - & - & 625 & - & 625 & 312.5 & - \\
\hline 1/10 Acetone & - & 625 & - & - & - & - & - & 312.5 & - \\
\hline 1/10 Distilled water & - & - & - & - & - & - & - & - & - \\
\hline 1/10 Methanol & - & - & - & - & - & - & - & - & - \\
\hline Ciprofloxacin & 0.25 & 0.25 & 0.007 & 0.125 & 0.125 & 0.007 & - & - & - \\
\hline Amphotericin B & - & - & - & - & - & - & 0.5 & 1 & 1 \\
\hline
\end{tabular}

S.a: S.aureus ATCC 29213; S.e: S. epidermidis ATCC 12228; E.c: E. coli ATCC 25922; K.p: K. pneumoniae ATCC 4352;

P.a: P. aeruginosa ATCC 27853; P.m: P. mirabilis ATCC 14153; C.a: C. albicans ATCC 10231; C.t: C. tropicalis ATCC 750; C.p: C. parapsilosis ATCC 22019.

Since biofilm-associated microorganisms are not affected by the therapeutically achievable concentrations of antimicrobial agents, current anti-biofilm therapies are generally focused on the inhibition of biofilm formation [22]. For this purpose, in addition to antimicrobial activities, we also investigated the in vitro activities of $A$. italicum extracts against the biofilm adhesion as well as the inhibition of the biofilm production of microorganisms by the MIC or subMIC values of the extracts. The $1 / 10$ concentrations of $A$. italicum Miller extracts were incubated with microorganisms in the wells of tissue culture microtiter plates, for 1,2 and $4 \mathrm{~h}$ at $37^{\circ} \mathrm{C}$ for bacteria and 2,4 and $6 \mathrm{~h}$ at $37^{\circ} \mathrm{C}$ for yeast to assess the adherence of microorganisms to the surface. According to our results $A$. italicum Miller ethanol extract inhibited the biofilm attachment of bacteria in a time dependent manner (Figure 1).

The highest adhesion inhibition rates (percentages) of ethanol extract varied over time for different bacteria; $57.91 \%$ (2 h) for P. aeruginosa, $46.29 \%$ (4 h) for $S$. aureus and $48.06 \%$ ( $1 \mathrm{~h}$ ) for $S$. epidermidis. However, it was found that acetone extracts had no effect on the adhesion inhibition experiments. Despite all, the 
FARMACIA, 2021, Vol. 69, 5

effects of extracts on Candida biofilm adhesion were not determined (Figure 1).
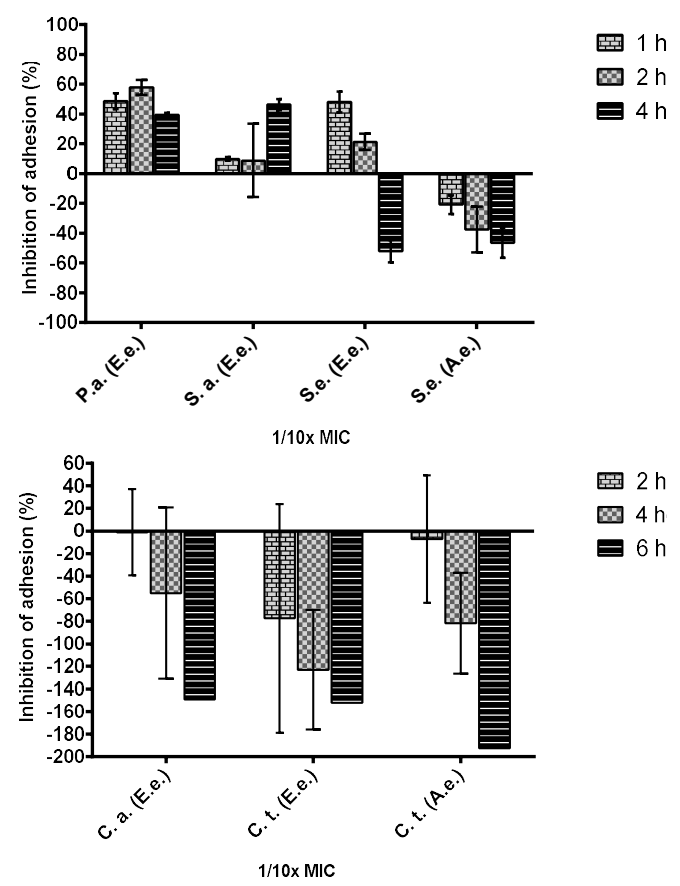

Figure 1.

Inhibition of bacteria (a) and yeast (b) biofilm attachment by ethanol extract (E.e) and acetone extract (A.e)

Then the effects of the MIC and subMICs of ethanol and acetone extracts on the inhibition of biofilm formation at $24 \mathrm{~h}$ were investigated and concentration dependent inhibition was detected (Figure 2). It was observed that the ethanol extract significantly inhibited the biofilm formation at the $1 \times$ MIC values. The inhibition rates of ethanol extract (at MIC values) against biofilm formation of $P$. aeruginosa, S. aureus and $S$. epidermidis were $66.94 \%, 58.35 \%$ and $32.53 \%$, respectively. The inhibition rate of acetone extract on MIC values against $S$. epidermidis was determined as $43.72 \%$. Inhibition of biofilm formation against Candida $s p$. was determined only for $C$. albicans (39.4\% at MIC). Our results suggest that $A$. italicum extracts are effective for inhibiting pre-formed biofilms. Also, inhibition of biofilm formation in early critical stages seems to be more applicable.

Investigation of new anticancer compounds in bioactive plants is thought to be a promising strategy for the treatment and prevention of diseases $[15,32]$. In our study, the cytotoxic and anti-proliferative effects of ethanol and acetone extracts from A. italicum were evaluated. For this purpose, HUVEC and MDA-MB231 cell lines were treated with ethanol and acetone extracts of A. italicum. Cell proliferation of breast cancer cells and endothelial cells were investigated in the presence of increasing amounts of $A$. italicum ethanol and acetone extracts. According to this study, viability of cells decreased to about $30 \%$ with 25 $\mu \mathrm{g} / \mathrm{mL}$ treatment with acetone extract in both cell lines. Furthermore, it was observed that the acetone extract was less toxic than the ethanol extract in HUVECs. Although ethanol extract did not have a remarkable effect on cell proliferation at lower doses (5 and $12.5 \mu \mathrm{g} / \mathrm{mL}$ ) in HUVECs, ethanol extract induced cell death in breast cancer cells at these low concentrations.

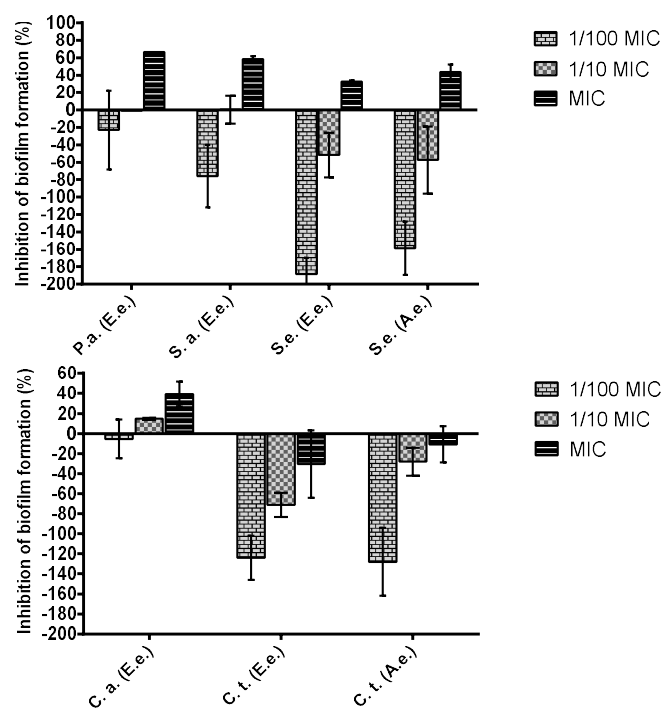

Figure 2.

Inhibition of bacteria (a) and yeast (b) biofilm formation by ethanol extract (E.e) and acetone extract (A.e)

In this study, ethanol extracts at concentrations of 5 $\mu \mathrm{g} / \mathrm{mL}$ and $12.5 \mu \mathrm{g} / \mathrm{mL}$ were less toxic in HUVECs however, these doses effectively reduced cell viability to approximately $32 \%$ and $66 \%$ respectively, on the breast cancer cell line showing the cytotoxic and anti-proliferative properties of $A$. italicum ethanol and acetone extracts, as the first time.

The cytotoxic activities of the $A$. italicum extracts are shown in Table II. While all extracts induced strong cytotoxicity in cell lines $(<20 \mathrm{mg} / \mathrm{mL})$, breast cancer cells showed striking sensitivity to treatment with $A$. italicum ethanol extract $(7.023 \pm 0.2601$; Table II). Measuring the degree of cytotoxicity has established three groups of extracts from natural sources according their activity levels: inactive $\left(\mathrm{IC}_{50}>100 \mathrm{mg} / \mathrm{mL}\right)$, moderately active $\mathrm{IC}_{50} 20-100 \mathrm{mg} / \mathrm{mL}$ ) and active $\left(\mathrm{IC}_{50}<20 \mathrm{mg} / \mathrm{mL}\right.$ ) were accepted by The U.S. National Cancer Institute (NCI) [33]. At $20 \mathrm{mg} / \mathrm{mL}$, the extract can be accepted as active, but also ethanol extract is less active in healthy cells in comparison with breast cancer cells. HUVECs, showed a slight differential effect between tumour and normal cells with ethanol extract treatment. 
A (HUVECs)

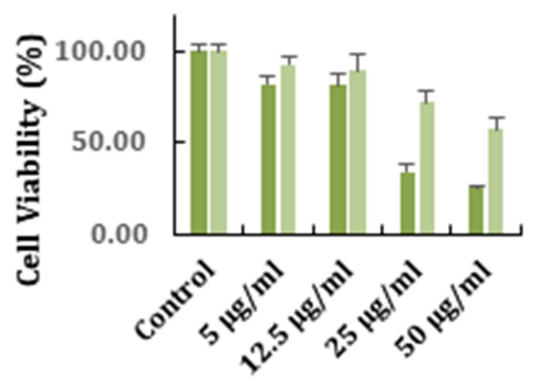

Concentration

B (MDA-MB-231)

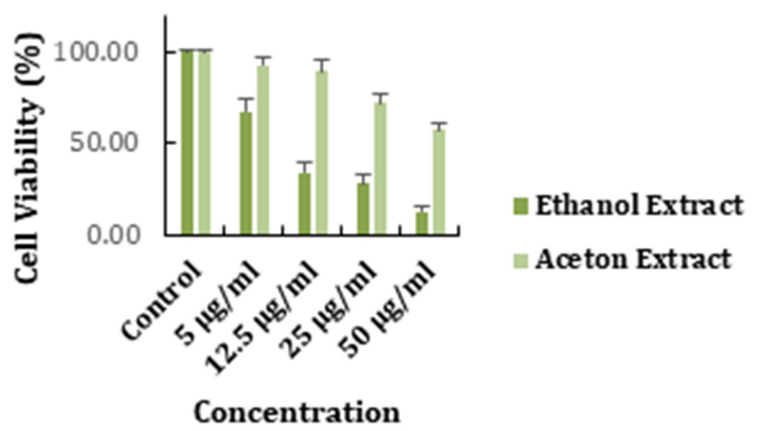

Figure 3 .

(A) HUVEC and (B) MDA-MB-231 cell lines were treated with ethanol and acetone extract of Arum italicum Mill. Cytotoxicity was measured by MTT assay. Cell viability was assessed at $570 \mathrm{~nm}$ by microplate reader after staining with MTT for $3 \mathrm{~h}$. Mean \pm SEM of at least triplicate determinations.

Table II

$\mathrm{IC}_{50}$ values $(\mu \mathrm{g} / \mathrm{mL})$ of Arum italicum ethanol and acetone extract on HUVECs and the breast cancer cell line. Human cancer cell lines were treated with different concentrations of $A$. italicum methanol and acetone extracts in 96-well microculture plates for $24 \mathrm{~h}$. $\mathrm{IC}_{50}$ values are expressed as mean \pm standard error of mean (S.E.M) of triplicate determinations.

\begin{tabular}{|l|c|}
\hline & Cell line and treatment $\mathrm{IC}_{50}(\mu \mathrm{g} / \mathrm{mL}) \pm \mathrm{SEM}$ \\
\hline HUVECs + A. italicum ethanol extract & $19.66 \pm 1.545$ \\
\hline HUVECs + A. italicum acetone extract & $19.08 \pm 0.1030$ \\
\hline MDA-MB-231 + A. italicum ethanol extract & $7.023 \pm 0.2601$ \\
\hline MDA-MB-231+ . italicum acetone extract & $18.12 \pm 0.5381$ \\
\hline
\end{tabular}

Furthermore, our results show that ethanol extract may have significant effects on the proliferation of cancer cells (Figure 3). Also in our results, ethanol extract of $A$. italicum on breast cancer cells yielded acceptable preliminary data. However, extracts should be studied more with respect to breast cancer and should be also evaluated for other cancer types in future studies.

\section{Conclusions}

In the present study, four different extracts of $A$. italicum, which are mainly used as medicine and food by East Mediterranean people, were studied. We found that two extracts of this plant (ethanol and acetone) displayed antimicrobial activities.

Interestingly, the two extracts of A. italicum also showed antibiofilm activity when used at subinhibitory concentrations. Additionally, our results suggest that the ethanol extract may have significant effects on the proliferation of cancer cells. Neverthless, further studies are needed in order for making $A$. italicum to be considered a viable candidate for the treatment of infectious diseases; biofilms as well as cancer.

\section{Conflict of interest}

The authors declare no conflict of interest.

\section{References}

1. Ahmad I A Husein, Modification of biologically active compounds from selected medicinal plants in Palestine, Master Thesis, An-Najah National University, Department of Chemistry and Department of Biology and Biotechnology, Nablus, Palestine, 2010.

2. Abdullah Al-Dhabi N, Valan Arasu M, Rejiniemon TS, In vitro antibacterial, antifungal, antibiofilm, antioxidant, and anticancer properties of isosteviol isolated from endangered medicinal plant Pittosporum tetraspermum. Evid Based Complement Alternat Med., 2015; 2015: 164261: 1-11.

3. Agalar H, Akalın Çiftçi G, Göger F, Kırımer N, Activity Guided Fractionation of Arum italicum Miller Tubers and the LC/MS-MS Profiles. Rec Nat Prod., 2018; 12(1): 64-75.

4. Aloush V, Navon-Venezia S, Seigman-Igra Y, Cabili S, Carmeli Y, Multidrug-resistant Pseudomonas aeruginosa: risk factors and clinical impact. Antimicrob Agents Chemother., 2006; 50(1): 43-48.

5. Alpinar K, Arum species in western part of Turkey, and the starch and protein contents of their tubers. Doga Bilim Dergisi A, 1985; 9(3): 473-483.

6. Alpınar K, Local uses and names for Arum L. species of west Turkey. Proceedings of the VI. Symposium on Plant Originated Crude Drugs (Ankara, May 1619, 1986) Ankara, 1987; 287-296.

7. Association for the Advancement of Wound Care (AAWC). Advancing your practice: understanding wound infection and the role of biofilms. Malvern, PA, USA. 2008. 
FARMACIA, 2021, Vol. 69, 5

8. Birteksoz-Tan AS, Zeybek Z, Hacioglu M, Savage $\mathrm{PB}$, Bozkurt-Guzel C In vitro activities of antimicobial peptides and ceragenins against Legionella pneumophila. J Antibiot (Tokyo), 2019; 72: 291-297.

9. Boyce P, The genus Arum. A Kew Magazine monograph. Royal Botanic Gardens, Kew, 1993; 72-73.

10. Bozkurt-Guzel C, Hacioglu M, Savage PB, Investigation of the in vitro antifungal and antibiofilm activities of ceragenins CSA-8, CSA-13, CSA-44, CSA-131, and CSA-138 against Candida species. Diagn Microbiol Infect Dis., 2018; 91(4): 324-330.

11. Branda SS, Vik S, Friedman L, Kolter R, Biofilms: the matrix revisited. Trends Microbiol., 2005; 13(1): 20-26.

12. Bryers JD, Medical biofilms. Biotechnol Bioeng., 2008; 100(1): 1-18.

13. Clinical and Laboratory Standards Institute. Methods for dilutionantimicrobial susceptibility tests for bacteria that grow aerobically, $7^{\text {th }}$ ed. Approved standard M7A7. Clinical and Laboratory Standards Institute, Wayne: PA, USA; 2006.

14. Clinical and Laboratory Standards Institute. Performance standards for antimicrobial susceptibility testing; $2^{\text {nd }}$ informational supplement. M100-S21. Clinical and Laboratory Standards Institute, Wayne: PA; 2011.

15. Cragg GM, Pezzuto JM, Natural Products as a Vital Source for the Discovery of Cancer Chemotherapeutic and Chemopreventive Agents. Med Princ Pract., 2016; 25(Suppl 2): 41-59.

16. Çolak F, Savaroğlu F, Ilhan S, Antibacterial and antifungal activities of Arum maculatum L. leaves extracts. J Appl Biol Sci., 2009; 3(3): 13-16.

17. Dosler S, Karaaslan E, Inhibition and destruction of Pseudomonas aeruginosa biofilms by antibiotics and antimicrobial peptides. Peptides, 2014; 62: 32-37.

18. El-Desouky SK, Kim KH, Ryu SY, Eweas AF, GamalEldeen AM, Kim KM, A New pyrrole alkaloid isolated from Arum palaestinum Boiss. and its biological activities. Arch Pharmacal Res., 2007; 30(8): 927-931.

19. Ertürk R, Çelik C, Kaygusuz R, Aydın H, Antimicrobial activities of commercial essential oils of thyme and mint. Cumhuriyet Med J., 2010; 32: 281-286.

20. Grayum MH, A summary of evidence and arguments supporting the removal of Acorus from the Araceae. Taxon, 1987; 36(4): 723-729.

21. Jakobsen TH, Bjarnsholt T, Jensen PØ, Givskov M, Høiby N, Targeting quorum sensing in Pseudomonas aeruginosa biofilms: current and emerging inhibitors. Future Microbiol., 2013; 8(7): 901-921.

22. Jorge $\mathrm{P}$, Lourenço A, Pereira MO, New trends in peptide-based anti-biofilm strategies: a review of recent achievements and bioinformatic approaches. Biofouling, 2012; 28(10): 1033-1061.

23. Karankı E, Ülkemizde yaygın olarak kullanılan bazı baharatların antimikrobiyal aktivitesinin belirlenmesi. Niğde Üniversitesi Fen Bilimleri Enstitüsü, Yüksek Lisans Tezi, Niğde, 2013, (available in Turkish).

24. Kulaksız B, Er S, Üstündağ-Okur N, Saltan-İsscan $\mathrm{G}$, Investigation of antimicrobial activities of some herbs containing essential oils and their mouthwash formulations. Turk J Pharm Sci., 2018; 15(3): 370-375.

25. Mansour O, Salamma R, Abbas L, Screening of Antibacterial Activity In vitro of Arum maculatum L. Leaves Extracts. Int J Pharm Sci Rev Res., 2015; 31(2): 231-234.

26. Meran M, Akkus PD, Kurkcuoglu O, Baysak E, Hizal G, Haciosmanoglu E, Unlu A, Karatepe N, Güner FS, Noncovalent Pyrene-Polyethylene Glycol Coatings of Carbon Nanotubes Achieve in Vitro Biocompatibility. Langmuir, 2018; 34(40): 12071-12082.

27. Mill RR, Araceae. In Davis PH, Mill RR, Tan K, (eds.) "Flora of Turkey and the E Aegean Islands". Edinburgh University Press, Edinburgh, 1984; 8: 41- 63.

28. Mill RR, Arum. In Davis PH, Mill RR, Tan K, (eds.) "Flora of Turkey and the E Aegean Islands" 236. Edinburgh University Press, Edinburgh, 1988; 10: 218-221.

29. Mai Farid M, Sameh Hussein, Lamyaa F Ibrahim, Mohammed Ali El Desouky, Amr Mohammed Elsayed, Ahmed El-Oqiah, Cytotoxic activity and phytochemical analysis of Arum palaestinum Boiss. Asian Pacific J Tropic Biomed., 2015; 5(11): 944-947.

30. Mohammed Mansour Saleh Saif, Abdulkawi Ali AlFakih, Malik Abdu M Hassan, Antibacterial activity of selected plant (Aqueous and methanolic) extracts against some pathogenic bacteria. $J$ Pharmacogn Phytochem., 2017; 6(6): 1929-1935.

31. Obeidat M, Antimicrobial activity of some medicinal plants against multidrug resistant skin pathogens. $J$ Medicin Plant Res., 2011; 5(16): 3856-3860.

32. Prakash O, Kumar A, Kumar P, Ajeet, Anticancer Potential of Plants and Natural Products: A Review. AJPS., 2013; 1(6): 104-115.

33. Skehan P, Storeng R, Scudiero D, Monks A, McMahon J, Vistica D, Warren JT, Bokesch H, Kenney S, Boyd MR, New colorimetric cytotoxicity assay for anticancer-drug screening. J Natl Cancer Inst., 1990; 82(13): 1107-1112.

34. Valarmathy K, Gokula Krishnan M, Kausar P, A study of antimicrobial activity of ethanolic extract of various plant leaves against selected microbial species. Int J Pharma Sci Res (IJPSR.), 2010; 1(8): 293-295. 